\title{
Synthetic CpG islands reveal DNA sequence determinants of chromatin structure
}

\author{
Elisabeth Wachter ${ }^{1}$, Timo Quante ${ }^{1}$, Cara Merusi ${ }^{1}$, Aleksandra Arczewska1, \\ Francis Stewart'2, Shaun Webb1, Adrian Bird ${ }^{1 *}$
}

${ }^{1}$ The Wellcome Trust Centre for Cell Biology, University of Edinburgh, Edinburgh, United Kingdom; ${ }^{2}$ Genomics and Biotechnology Centre, Technische Universitaet Dresden, Dresden, Germany
*For correspondence: A.Bird@ ed.ac.uk

Competing interests: The authors declare that no competing interests exist.

Funding: See page 14

Received: 16 May 2014

Accepted: 11 September 2014 Published: 26 September 2014

Reviewing editor: Anne C Ferguson-Smith, University of Cambridge, United Kingdom

(c) Copyright Wachter et al. This article is distributed under the terms of the Creative Commons Attribution License, which permits unrestricted use and redistribution provided that the original author and source are credited.

\begin{abstract}
The mammalian genome is punctuated by CpG islands (CGIs), which differ sharply from the bulk genome by being rich in $\mathrm{G}+\mathrm{C}$ and the dinucleotide $\mathrm{CpG}$. CGls often include transcription initiation sites and display 'active' histone marks, notably histone $\mathrm{H} 3$ lysine 4 methylation. In embryonic stem cells (ESCs) some CGls adopt a 'bivalent' chromatin state bearing simultaneous 'active' and 'inactive' chromatin marks. To determine whether CGI chromatin is developmentally programmed at specific genes or is imposed by shared features of CGI DNA, we integrated artificial CGI-like DNA sequences into the ESC genome. We found that bivalency is the default chromatin structure for CpG-rich, G + C-rich DNA. A high CpG density alone is not sufficient for this effect, as $A+$ T-rich sequence settings invariably provoke de novo DNA methylation leading to loss of CGI signature chromatin. We conclude that both CpG-richness and G + C-richness are required for induction of signature chromatin structures at CGls.
\end{abstract}

DOI: 10.7554/eLife.03397.001

\section{Introduction}

CpG islands (CGIs) are stretches of atypical genomic DNA sequences that mark most gene promoters (Bird, 1986; Deaton and Bird, 2011). Though individually unique in nucleotide sequence, mammalian CGls share two features that often correlate but can vary independently: a G + C-rich base composition ( $65 \%$ vs $40 \%$ for the bulk genome) and high density of the dinucleotide CpG (5-10-fold higher than the bulk genome). Whereas bulk genomic DNA is globally methylated, CGIs associated with promoters invariably lack DNA methylation. It has been proposed that CGls function as generic platforms for gene regulation, probably via proteins that bind to $\mathrm{CpG}$ and influence chromatin modification (Blackledge and Klose, 2011; Deaton and Bird, 2011). This hypothesis has gained credence due to accumulating evidence that enrichment or depletion of specific chromatin marks at CGls is linked to proteins that bind to unmethylated CpG. So far, all such proteins possess CXXC zinc finger domains that bind specifically to the CpG dyad in duplex DNA (Lee et al., 2001). Cfp1, for example, is a CXXC domain-containing component of the Set1/COMPASS complex (Lee and Skalnik, 2005), which generates H3K4 methylation, a signature chromatin mark at non-methylated CGls (Bernstein et al., 2006; Guenther et al., 2007). Accordingly, Cfp1 is concentrated at CGls as determined by chromatin immunoprecipitation (ChIP) and its absence is associated with reduced H3K4 methylation at many CGls (Thomson et al., 2010; Clouaire et alı, 2012). The H3K4 methyltransferases MII1 and MII2 are also CXXC proteins and each is found at CGls in mouse embryonic stem cells (ESCs) as determined by ChIP-Seq (Hu et al., 2013; Denissov et al., 2014). Similarly the $\mathrm{CXXC}$ domain-containing proteins $\mathrm{Kdm} 2 \mathrm{a}$ and $\mathrm{Kdm} 2 \mathrm{~b}$ are enriched at CGls. $\mathrm{Kdm} 2 \mathrm{a}$ is an $\mathrm{H} 3 \mathrm{~K} 36$ demethylase that contributes to depletion of H3K36me at CGI promoters (Blackledge et al., 2010), 
eLife digest The building blocks of DNA are four molecules commonly named 'A', 'T', 'C' and ' $G$ '. The order of these DNA letters in a gene contains the instructions to make specific proteins or other molecules. Other stretches of DNA contain codes that direct the cell's machinery to genes that need to be switched on or switched off. The start of a gene, for example, has a stretch of DNA called a promoter, which is where the molecular machinery that switches on the gene is assembled.

A human cell can contain over two and half metres of DNA. To get this length to fit inside the cell, the DNA is wrapped tightly around proteins to form a structure called chromatin. However, this packing can make it difficult to access the right gene at the right time. As such, chromatin is often marked with small chemical tags that earmark which genes should be either activated or inactivated, and/or that cause the DNA to unpack.

Most gene promoters contain a sequence of DNA with many Cs and Gs found one after the other, called a CpG island. Researchers have previously shown that the chromatin of CpG islands has two types of chemical markings-one that normally marks active genes, and another that often marks inactive genes. It was suggested that having both kinds of markings allows CpG islands to prime nearby genes, so that they are ready to be quickly switched on or off as the cell develops. However, the features of the DNA sequence in these CpG islands that are important for this process had not been directly tested.

Wachter et al. have now inserted an artificial DNA sequence that included a CpG island into mouse stem cells. The chromatin around these $\mathrm{CpG}$ islands was readily marked with both activating and inactivating chemical marks. Furthermore, by changing the sequence of the artificial DNA, Wachter et al. revealed that these chemical marks were only added when the DNA sequences contained a lot of Cs followed by Gs. Other artificial sequences with lots of $\mathrm{Cs}$ and $\mathrm{Gs}$, but where Gs were rarely found immediately after the Cs, had neither of the two chemical marks on the chromatin. This suggests that nearby genes would be harder to locate and activate as the cell grows and develops. On the other hand, when the DNA contained a lot of As and Ts, the chemical marks were added directly to the DNA (rather than to the chromatin)—and this prevented both the activating and the inactivating chemical marks being added to the chromatin.

Now that the common features of CpG islands that influence chromatin are known, the next step is to find out how this is achieved. Further work will be needed to uncover which proteins in a cell interpret these DNA sequence such that nearby genes can be switched on or off.

DOI: 10.7554/eLife.03397.002

whereas $\mathrm{Kdm} 2 \mathrm{~b}$ facilitates recruitment of the PRC1 complex to transcriptionally silent CGls (Farcas et al., 2012; Wu et al., 2013).

Previous studies have shown that CGI-like DNA sequences can impose an altered chromatin state in ESCs. Promoter-less CGI-like DNA sequences of invertebrate origin in mouse ES cells were initially shown to cause local enrichment of trimethylation of lysine 4 of histone $\mathrm{H} 3(\mathrm{H} 3 \mathrm{~K} 4 \mathrm{me} 3)$ and to recruit the CpG binding protein Cfp1 (Thomson et alo, 2010). Similar experiments using G + C-rich DNA derived from bacteria created chromatin marked by both $\mathrm{H} 3 \mathrm{~K} 27 \mathrm{me} 3$ and $\mathrm{H} 3 \mathrm{~K} 4 \mathrm{me} 3$ (Mendenhall et al., 2010). Whereas H3K4me3 is characteristic of active promoters, H3K27me3 is associated with transcriptional repression via the polycomb complex. The coincidence of these two marks in so-called 'bivalent' chromatin is thought to be a feature of genes that are poised to become either active or silent during early development (Azuara et al., 2006; Bernstein et al., 2006; Voigt et al., 2013). Many native CGls in ESCs adopt a 'bivalent' chromatin structure when transcriptionally silent.

Despite evidence that CXXC proteins play a role at CGls, the hypothesis that CpG density is the critical determinant of CGI function has not been directly tested. Here we vary the DNA sequence composition of artificial promoter-less CGls to assess the relative importance of G + C-richness and high CpG density. Our assay relies upon chromosomal integration of artificial CGI-like sequences into the genome of ESCs. We show that a bivalent chromatin configuration and absence of DNA methylation represent the default state of biologically inert CGI-like DNA sequences. While a high CpG density is essential, it is not sufficient to guarantee the bivalent chromatin structure, as CpG-rich DNA sequences with a $\mathrm{G}+\mathrm{C}$-poor average base composition do not acquire this chromatin signature. In fact A + T-rich, $\mathrm{G}+\mathrm{C}$ poor insertions with a $\mathrm{CpG}$ frequency matching that of CGls consistently become 
DNA methylated in ESCs, although the bivalent configuration can be restored if the dominant DNA methylation is removed. Our findings demonstrate that $\mathrm{CpG}$-richness is essential for the formation of bivalent chromatin, whereas $G+C$-richness is required to exclude DNA methylation, which when present is dominant over the other chromatin marks.

\section{Results}

\section{Formation of a novel bivalent domain at artificial CGI-like sequences}

Comparison between CGls and an equivalent number of sequences from the bulk genome shows that both $\mathrm{CpG}$ frequency and $\mathrm{G}+\mathrm{C}$ richness are distinct in CGls compared with bulk genomic DNA of mouse (Figure 1A). A previous study showed that bacterial DNA with CGI-like features organised bivalent chromatin in ESCs (Mendenhall et al., 2010). In order to verify and extend this result we introduced CGI-like DNA sequences of 1000 nucleotide pairs (the average length of native CGIs) into a bacterial artificial chromosome (BAC) containing a human 'gene desert' using recombineering (See Figure 1-figure supplement 1). A computer-generated CGI-like sequence (Artificial CGI 1) was designed with a CpG frequency of one per $\sim 10$ base pairs and a base composition of $65 \% \mathrm{G}+\mathrm{C}$ (Figure 1A, Figure 1-figure supplement 2 and Figure 1-source data 1). A second CGI-like sequence (PuroGFP; Figure 1A, Figure 1-figure supplement 2 and Figure 1-source data 1) was of prokaryotic origin, being derived from a promoter-less bacterial puromycin gene adjacent to codonoptimised green fluorescent protein coding sequence (Thomson et al., 2010). All constructs lack a promoter, allowing us to focus on the interaction between DNA sequence and chromatin modification without the complicating involvement of transcription. The gene desert regions flanking CGl-like sequences are intended to insulate against effects of the genomic and chromatin environment at different BAC integrations sites.

Three independently transfected stable ESC lines with low copy number random integrations of the BAC containing Artificial CGI 1 and one cell line with the PuroGFP CGI were selected for ChIP analysis (See Figure 1-figure supplement 1). As controls we monitored active genes (Sox2 and Gapdh), which are marked by $\mathrm{H} 3 \mathrm{~K} 4 \mathrm{me} 3$, an endogenous bivalent gene (Hoxc8), which carries both H3K27me3 and $\mathrm{H} 3 \mathrm{~K} 4 \mathrm{me} 3$, and an inter-genic region of chromosome 15 (m15), which bears neither mark. The CGl-like insertions consistently generated a bivalent chromatin structure marked by $\mathrm{H} 3 \mathrm{~K} 4 \mathrm{me} 3$ and H3K27me3 (Figure 1B,C and Figure 1-figure supplement 1). We refer to DNA sequence domains as bivalent using the convention that $\mathrm{H} 3 \mathrm{~K} 4 \mathrm{me} 3$ and $\mathrm{H} 3 \mathrm{~K} 27$ me 3 marks coincide at a single integration site. It is possible that some cells in the population harbour an integrant marked by only one of these marks whereas other cells possess only the other mark. This configuration has not been detected at the few ESC bivalent domains tested so far. More likely is that the two marks are interspersed at a given bivalent sequence domain, though we did not test this experimentally (See Voigt et al., 2013). The levels of $\mathrm{H} 3 \mathrm{~K} 4 \mathrm{me} 3$ at the artificial CGI were similar to those at the endogenous bivalent gene Hoxc8, whereas H3K4me3 levels in the DNA sequences flanking the CGI were unaffected by the insertion. H3K27me3 was less discrete, spreading variably into flanking regions of the human BAC, but Suz12, a component of the PRC2 complex that deposits the H3K27me3 mark, was tightly localised to the CGI-like sequence in each case. We tested an unrelated artificial CGI-like sequence with similar overall sequence properties (Artificial CGI 2; Figure 1-figure supplement 1), this time integrated at a recombination cassette within the beta globin locus of mouse ESCs (Lienert et al., 2011). Independent replicate stable transformant cell lines again showed consistent presence of a bivalent chromatin structure (data not shown). The DNA methylation status of the integrated artificial CGls was investigated by bisulfite sequencing. This showed that all the insertions reproducibly maintained a low level of DNA methylation (Figure 1D; Figure 1-figure supplement 1). DNA methylation levels at CGI-like sequences inserted into the gene desert ( 10\%) were consistently somewhat higher than in the cassette exchange system $(0.5 \%)$ and were somewhat higher than an endogenous control CGI in the same DNA samples (D/x5; 4-5\%, data not shown). Despite this variability, it is evident that all of these artificial DNA sequences maintain a largely non-methylated status.

\section{H3K4me3 at an artificial CGI is independent of Cfp1 and RNA polymerase II}

To test whether these promoter-less artificial DNA sequences were transcriptionally inert, we performed ChIP with antibodies recognising three differentially phosphorylated forms of RNA polymerase II in 


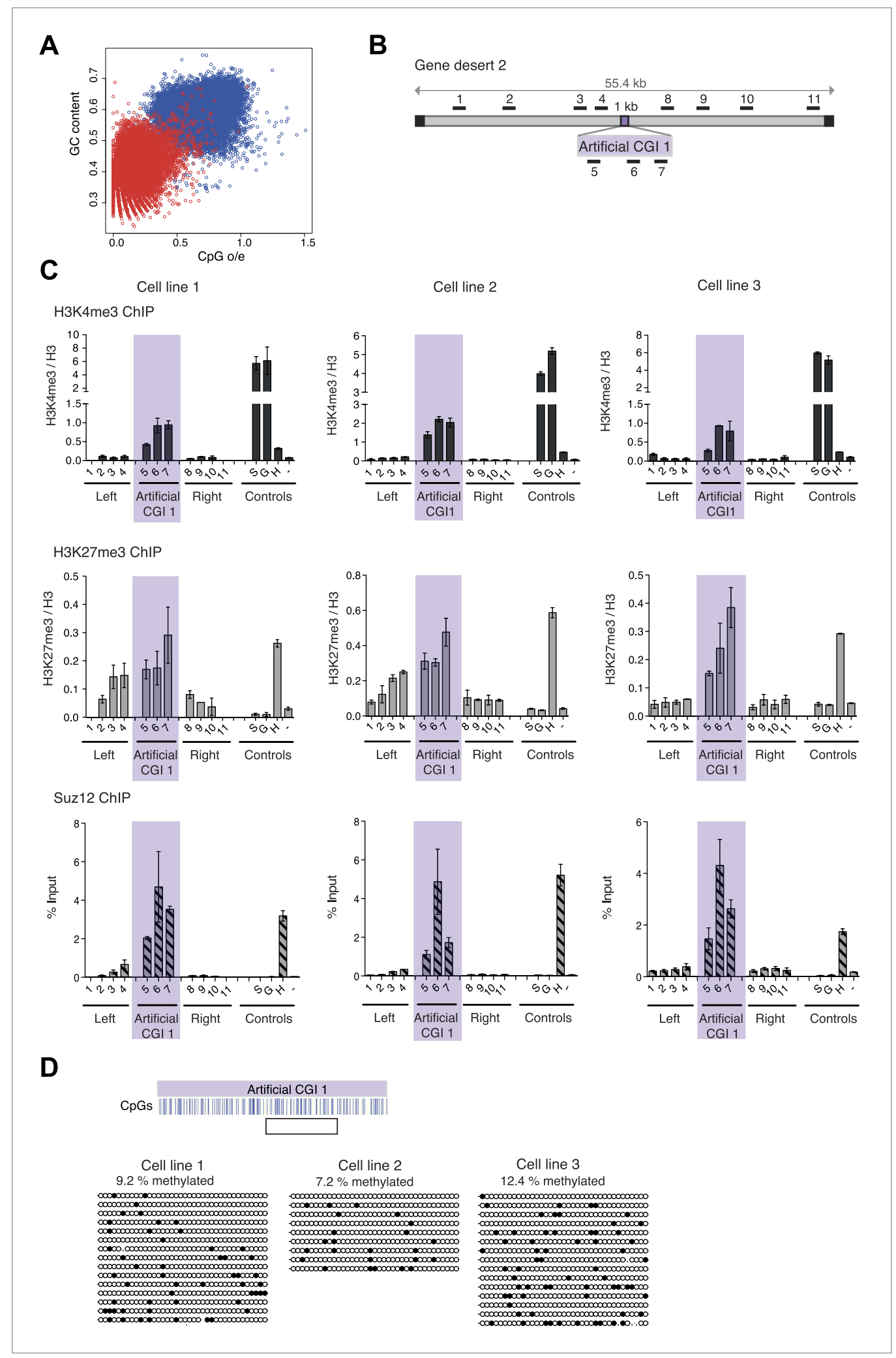

Figure 1. A novel bivalent chromatin domain is formed at promoter-less artificial CGI-like sequences integrated within a gene desert in mouse ESCs. (A) CpG frequency and G + C content of CGls in the mouse genome (blue circles) and an equivalent number of equal-sized (1000 base pair) random fragments of bulk genomic DNA (red circles). (B) Map of human gene desert 2 (grey bars; Chr1:81,106,616-81,153,886) showing the integration site of the Figure 1. Continued on next page 
Figure 1. Continued

Artificial CGI-like construct (purple box). Black boxes at the ends indicate bacterial BAC sequences. Black bars above indicate the position of Q-PCR amplicons (not to scale). (C) Representative anti-H3K4me3 and H3K27me3 ChIP profiles (normalized to H3 ChIP) and Suz12 ChIP profiles (\% Input; $n=3$ ) for three independently transfected cell lines. Shaded box includes primers spanning the Artificial CGI. ChIP control amplicons are derived from the TSS of the active genes Sox2 (S) and GAPDH (G); the TSS of bivalent gene Hoxc8 (H) and an inconspicuous negative control region on mouse chromosome 15 (-). Error bars indicate the standard deviation of PCR replicates. (D) Bisulfite sequencing of the three cell lines shown in (C). In the map above, blue strokes show $\mathrm{CpGs}$ in the CGI-like insert and the clear box indicates the bisulfite amplicon. Methylated and unmethylated CpGs are depicted as filled and open circles, respectively.

DOI: 10.7554/eLife.03397.003

The following source data and figure supplements are available for figure 1:

Source data 1.

DOI: 10.7554/eLife.03397.004

Figure supplement 1. Bivalent chromatin at artificial CGI-like sequences in mouse ESCs. DOI: 10.7554/eLife.03397.005

Figure supplement 2. Synthetic DNA elements with different sequence properties. DOI: 10.7554/eLife.03397.006

replicate cell lines. None displayed a peak over the insert, whereas control active genes were RNA polymerase-positive as expected (Figure 2A and Figure 2-figure supplement 1). Consistent with the absence of RNA polymerase, we did not detect significant peaks of histone acetylation over the CGI-like insertions (Figure 2B). In summary, data derived from three distinct promoter-less CGI-like sequences indicate that bivalent chromatin is the default state for transcriptionally inert CGI-like DNA in ESCs.

We next asked whether the CXXC protein Cfp1 is enriched at the CGI-like sequences. To facilitate detection of Cfp1, we introduced the BAC containing the artificial CGI into a transgenic cell line expressing a Cfp1-GFP fusion protein (Denissov et al., 2014). Having verified that a bivalent domain was formed at the artificial CGI in these cells (data not shown), ChIP was performed on three independent cell lines using an anti-GFP antibody. We consistently observed discrete enrichment of Cfp1 at the CGl-like insertion (Figure 2C). To determine whether the formation of a bivalent domain at the inserted artificial CGI-like sequence was dependent on Cfp1, the artificial CGI was introduced into Cfp1-/- mouse ES cells (Carlone and Skalnik, 2001) and three independent lines were analysed by ChIP. H3K4me3 levels at the artificial CGI were clearly detectable in the Cfp1-/- cells, indicating that $\mathrm{Cfp} 1$ is not required for the formation of H3K4me3 levels at the bivalent domain (Figure 2D). Depletion of Cfp1 was previously reported to preferentially cause a decrease of $\mathrm{H} 3 \mathrm{~K} 4 \mathrm{me} 3$ at active genes without affecting non-productive genes (Clouaire et al., 2012). In agreement with this finding, we observed reduced H3K4me3 at the active control gene Sox2 compared to wildtype cells (Compare Figures 2D and $1 \mathrm{C}$ ). We also followed the fate of chromatin modifications during differentiation of ESCs to neuronal progenitor cells (Figure 2-figure supplement 1B) and found a consistent drop in H3K4me3 accompanied by persistent or increased H3K27me3 (Figure 2-figure supplement 1). This transition from bivalency to H3K27me3 marking alone matches that at native CGI-associated genes that remain transcriptionally silent during differentiation (Bernstein et al., 2006).

\section{A high CpG frequency is necessary for the creation of bivalent domain}

Although $\mathrm{G}+\mathrm{C}$ content and $\mathrm{CpG}$ frequency are related features, they can be varied independently (Figure 1A). To establish the importance of these features for determination of bivalent chromatin, we varied $\mathrm{CpG}$ frequency and $\mathrm{G}+\mathrm{C}$ content in 1000 base pair long artificial DNA sequences (Figure 1-figure supplement 2 and Figure 1-source data 1). An artificial CGI with a base composition similar to that of a normal CGI $(65 \% \mathrm{G}+\mathrm{C})$ but with a low density of CpGs, similar to that of the bulk genome (1 CpG/100 bp), was designed (Low CpG / High G + C). This Low CpG / High G + C sequence failed to create bivalent chromatin as neither H3K4me3 nor H3K27me3 was detected in three independent ESC lines (Figure 3A). We note that the relative values of control and experimental data points are consistent between experiments although we observe variability in the absolute precipitation levels due to the use of different antibody suppliers between experiments over an extended time period. Our conclusion from this data is that a $\mathrm{G}+\mathrm{C}$-rich base composition alone is insufficient to recruit either $\mathrm{H} 3 \mathrm{~K} 4 \mathrm{me} 3$ or $\mathrm{H} 3 \mathrm{~K} 27 \mathrm{me} 3$. 


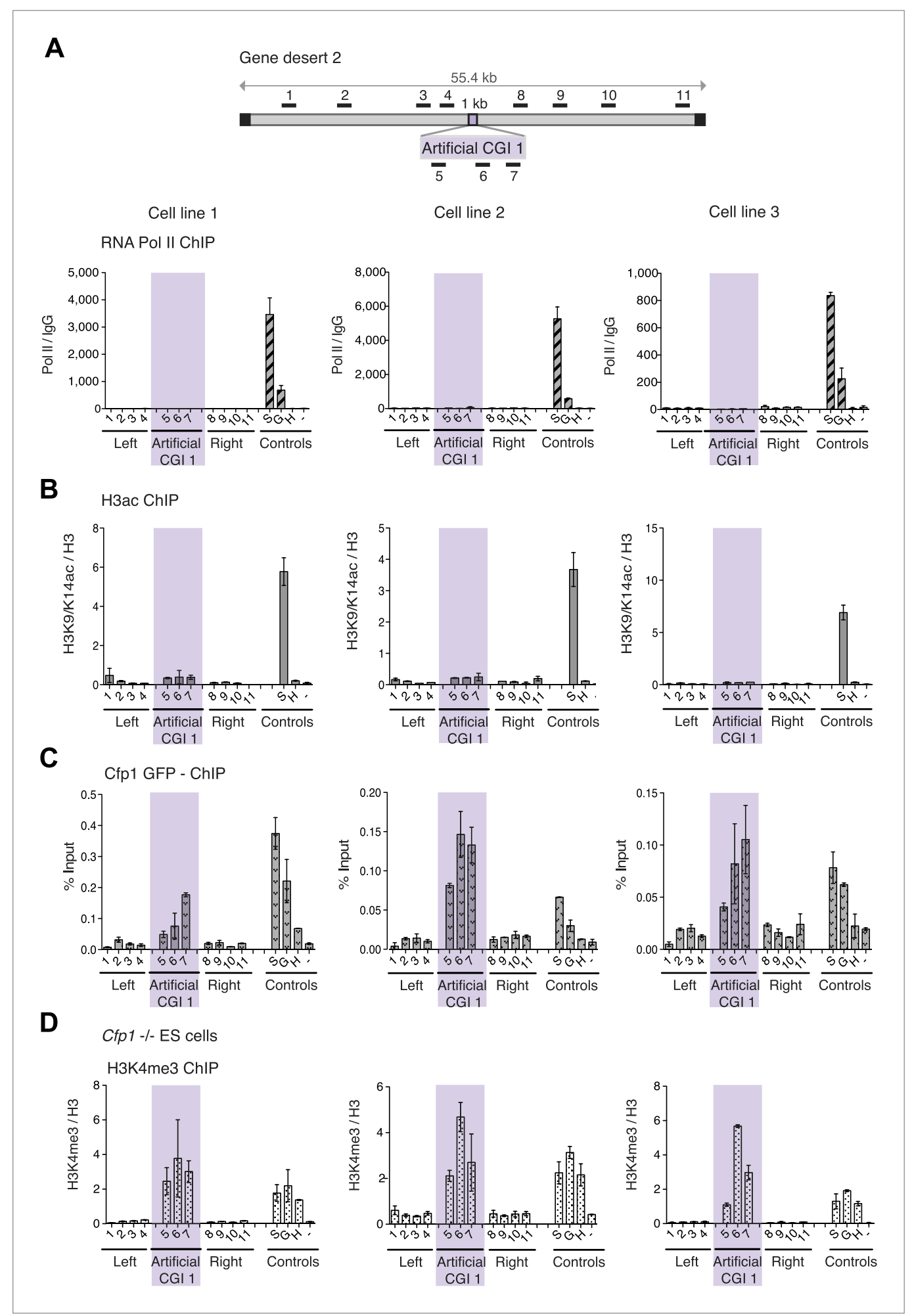

Figure 2. H3K4me3 at a promoter-less artificial CGI forms independently of Cfp1 and RNA polymerase II. (A) Map of gene desert 2 with integrated Artificial CGI-like construct labeled as in Figure 1B. Representative ChIP with an antibody specific for the N-terminus of RNA polymerase II for three independent cell lines (\% Input over IgG; $n=2$ ). (B) Representative anti-H3K9/K14 acetylation ChIP profiles for three independently transfected cell lines normalized to H3 ChIP $(n=2)$. (C) Mouse ES cells expressing GFP-tagged Cfp1 were transfected with Artificial CGI construct and bound Cpf1 was assayed by ChIP with anti-GFP antibodies in three independent cell lines Figure 2. Continued on next page 
Figure 2. Continued

$(n=2)$. (D) Representative anti-H3K3me3 ChIP for three independent Cfp1-/- mouse ES cells transfected with the Artificial CGI construct $(n=2)$. Control ChIP amplicons are as in Figure 1C. Error bars indicate standard deviation

of PCR replicates.

DOI: 10.7554/eLife.03397.007

The following figure supplement is available for figure 2:

Figure supplement 1. H3K4me3 at an artificial CGI independent of Cfp1 and RNA polymerase II. DOI: 10.7554/eLife.03397.008

\section{A + T-rich CGls become reproducibly DNA methylated}

This result raised the possibility that $\mathrm{CpG}$ frequency alone determines the chromatin state, with $\mathrm{G}+\mathrm{C}$ content playing no role. To test this idea, we generated four different artificial DNA sequences that were CpG-rich to the same level as typical CGls (10 CpGs/100 bp), but relatively A + T-rich in overall base composition (three of $40 \%$ and one of $50 \%$ G + C on average; Figure 1-figure supplement 2 and Figure 1-source data 1). Contrary to expectation, none of these insertions generated a focus of bivalent chromatin in multiple independent cell lines (Figure 4A and Figure 4-figure supplement 1). A potential explanation for this finding came from an analysis of DNA methylation status, which showed that in replicate cell lines the CGls had all become densely methylated at CpGs (Figure 4B and Figure 4-figure supplement 2). The striking contrast between the consistent methylation-free status of three separate $\mathrm{G}+\mathrm{C}$-rich, $\mathrm{CpG}$-rich integrants and the reproducible dense methylation of four unrelated A + T-rich, CpG-rich sequences of the same length indicates that base composition is a strong determinant of DNA methylation status. A plot of $\mathrm{G}+\mathrm{C}$-content against percentage $\mathrm{CpG}$ methylation showed a sharp transition between 50 and $60 \% \mathrm{G}+\mathrm{C}$ (Figure 4D). Interestingly, a CGIlike insertion with a base composition of 55\% G + C (MeCP2-eGFP) studied previously (Thomson et al., 2010) showed an intermediate DNA methylation level, suggesting that it lies on the transition point for triggering de novo methylation (Figure 4D).

\section{Removal of DNA methylation restores the bivalent domain}

The results indicate that DNA methylation is dominant over both $\mathrm{H} 3 \mathrm{~K} 4 \mathrm{me} 3$ and $\mathrm{H} 3 \mathrm{~K} 27 \mathrm{me} 3$, as in its presence neither chromatin mark is observed at the artificial CGIs. To test this hypothesis, we asked if removal of DNA methylation could restore bivalent chromatin at A + T-rich CpG-rich sequences by using mutant ESCs lacking the de novo DNA methyltransferases Dnmt 3a and Dnmt 3b (Okano et al., 1999), which display severe DNA hypomethylation (Figure 4-figure supplement 2). To ensure that histone modifying enzyme activities are not disrupted in the Dnmt 3a/3b double knock out cells, we generated stable cell lines with the artificial CGI-containing BAC and confirmed that a bivalent domain was observed over the insertion (Figure 4-figure supplement 2). When the High CpG /High A + T construct was introduced into Dnmt 3a/3b knock out cells it now remained unmethylated, and importantly, bivalent chromatin was detected at the inserted sequence (Figure 4C). We noticed that H3K4me3 was reproducibly weaker than controls in Dnmt 3a/Dnmt 3b double mutant cells, whereas a robust $\mathrm{H} 3 \mathrm{~K} 27$ me3 signal was obtained. This may indicate that $A+$ T-rich DNA is less able to recruit H3K4me3 despite its high CpG density. The dominance of the polycomb-associated H3K27me3 mark at A + T-rich CGls was also seen when DNA methylation was partially reduced by growing cells for 10 days in $2 \mathrm{i}$ medium, which enhances the pluripotent state. In line with previous reports (Ficz et al., 2013; Habibi et al., 2013), we found that the average level of genomic CpG methylation was reduced from $\sim 95 \%$ to $\sim 55 \%$ (Figure 4-figure supplement 2). Whereas cells grown in serumcontaining medium lacked both the tested histone marks, 2i-grown cells displayed a strong increase in H3K27me3 without the appearance of noticeable H3K4me3 (Figure 4-figure supplement 2). We conclude that while $\mathrm{CpG}$ frequency is a key feature of CGIs that determines the signature chromatin marks at CGls, A + T-richness confers an intrinsic susceptibility to de novo methylation that is dominant over these chromatin modifications (Figure 4E).

\section{Status of endogenous DNA domains with atypical CpG or G + C composition}

Our study assessed the role of G + C-richness vs CpG-richness on chromatin structure by experimentally varying these sequence parameters individually in synthetic DNA domains. The question arises: 


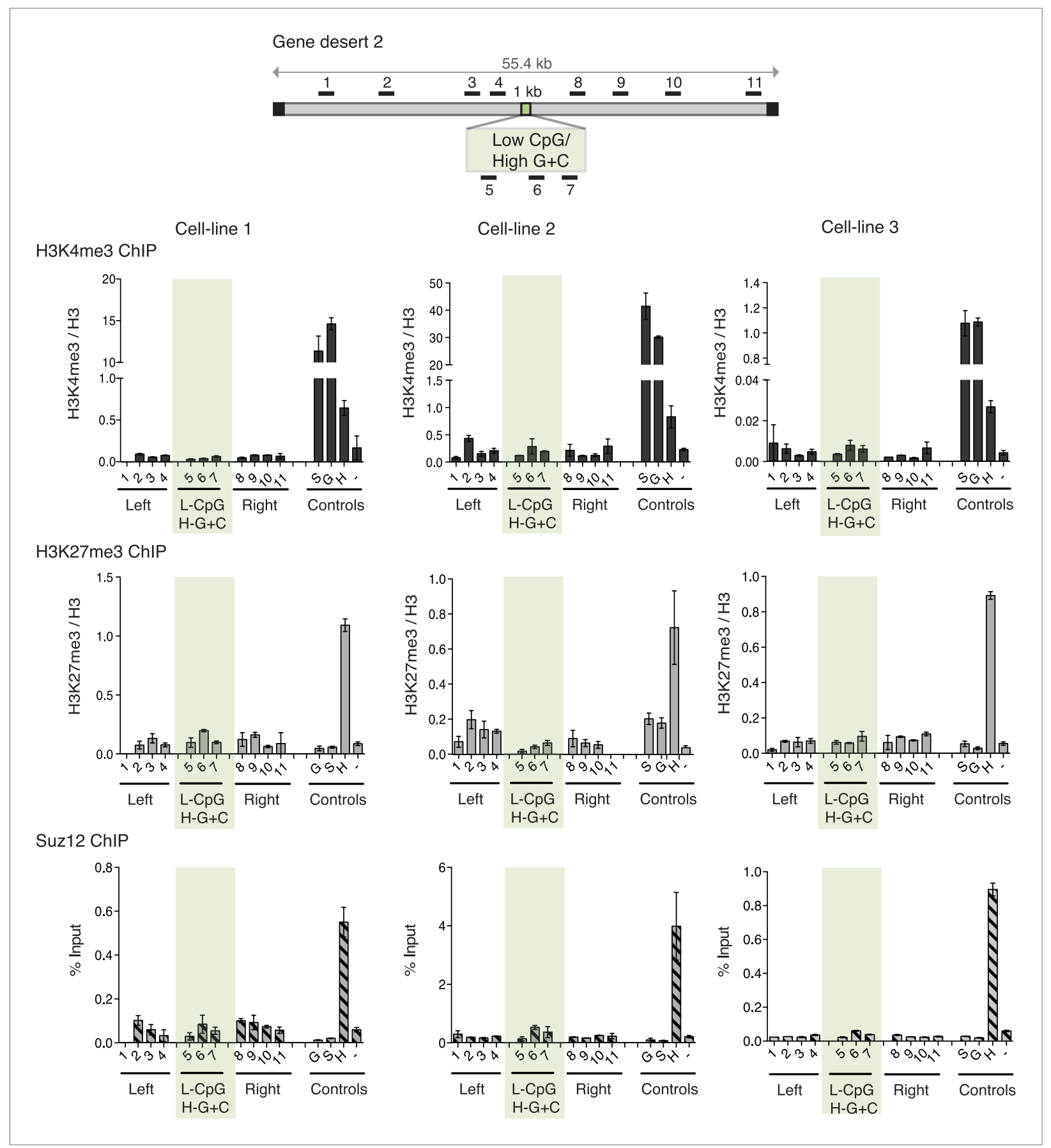

Figure 3. High $\mathrm{G}+\mathrm{C}$ content is not sufficient to create a bivalent chromatin domain. Map of gene desert 2 showing the integration site of the Low $\mathrm{CpG} / \mathrm{High} \mathrm{G}+\mathrm{C}(\mathrm{L}-\mathrm{CpG} / \mathrm{H}-\mathrm{G}+\mathrm{C}$ ) construct labeled as in Figure 1B. Representative anti-H3K3me3 and H3K27me3 ChIP profiles (normalized to H3) and Suz12 ChIP profiles (\% Input; $n=3$ ) are shown for three independent transfected cell lines. Shaded bar includes primers spanning the Low CpG / High G + C construct. Control ChIP amplicons are as in Figure 1C. Error bars indicate standard deviation of PCR replicates.

do equivalent atypical sequences exist naturally in the mouse genome and if so what is their chromatin modification status? We searched first for $G+C$-rich $(\geq 61 \%), C p G$ deficient $(\leq 1 / 100 \mathrm{bp})$ sequences of $\geq 500$ bp in length and identified 1954 examples. None of these coincided with bivalent chromatin in ESCs, in agreement with our results using synthetic DNA. To determine if A + T-rich, CpG-rich sequences also exist naturally in mice, we divided the genome into windows of $100 \mathrm{bp}$ and calculated the $G+C$ content and $C p G$ density of each. To ensure that we selected regions with profiles 


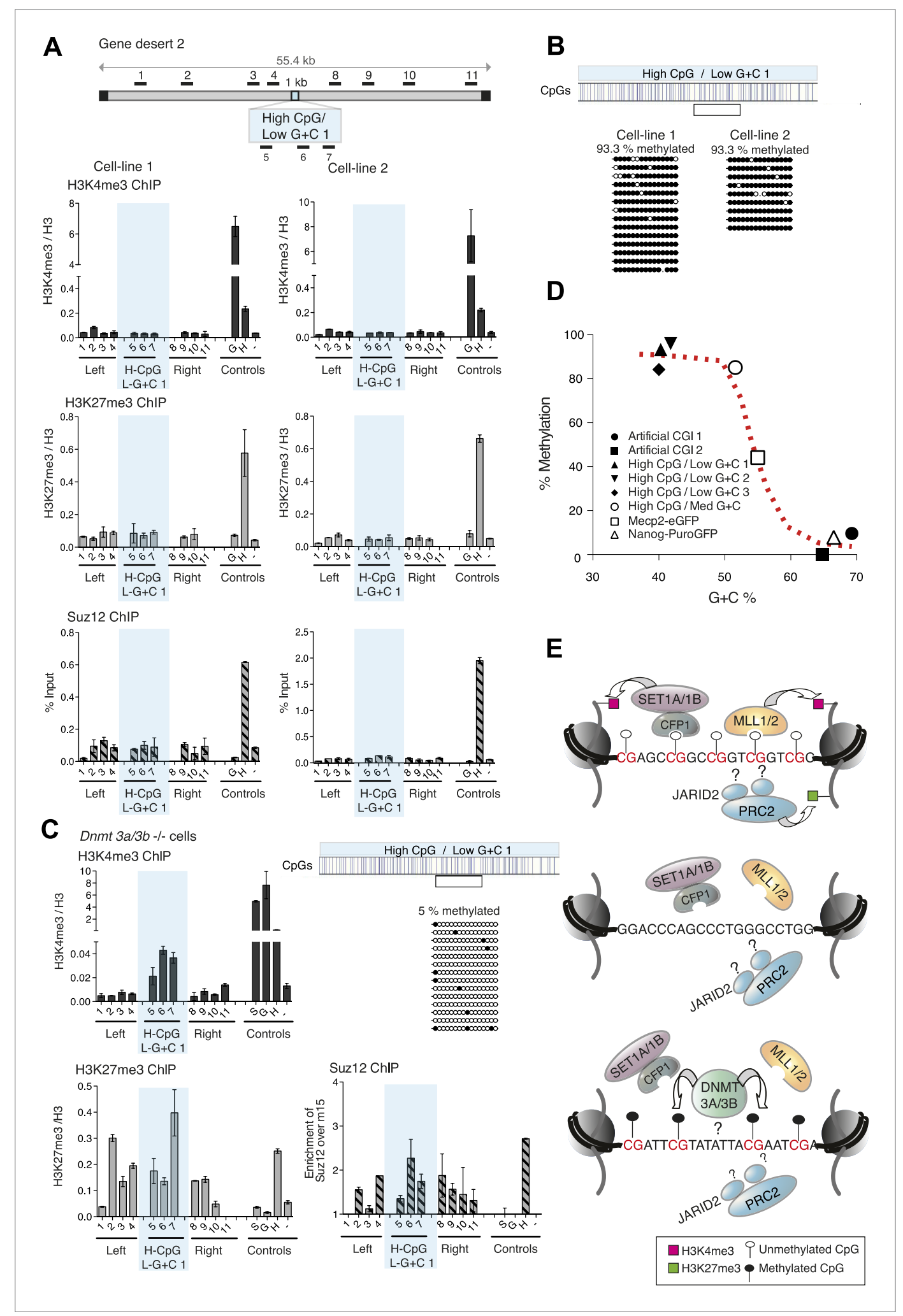

Figure 4. CpG-rich DNA sequences on an A + T-rich background fail to form bivalent chromatin and reproducibly acquire DNA methylation. (A) Above: Map of gene desert 2 indicating the integration site of the High CpG / Low $\mathrm{G}+\mathrm{C} 1(\mathrm{H}-\mathrm{CpG} / \mathrm{L}-\mathrm{G}+\mathrm{C}$ 1) construct as in Figure 1B. Representative anti-H3K4me3, H3K27me3 and Suz12 ChIPs shown $(n=3)$ for each of two independently transfected cell lines (Third line not shown). The shaded bar includes Figure 4. Continued on next page 
Figure 4. Continued

primers spanning the High CpG / Low G + C 1 construct. (B) Bisulfite sequence analysis of the two cell lines shown in (A). Clear box indicates bisulfite amplicon. In the map above, blue strokes show CpGs in the CGI-like insert and the clear box indicates the bisulfite amplicon. Methylated and unmethylated $\mathrm{CpGs}$ are depicted as filled and open circles, respectively. (C) The High CpG / Low G + C construct was integrated into Dnmt 3a-/- Dnmt 3b-/- double mutant mouse ES cells. Representative H3K4me3, H3K27me3 and Suz12 ChIPs are shown $(n=3)$. Upper right panel shows bisulfite sequence analysis of a cell line containing the High CpG / Low G + C construct in Dnmt 3a/b -/- cells, presented as in panel (B). (D) The relationship between $\mathrm{G}+\mathrm{C}$ content of constructs analysed in this study and their DNA methylation status. Data for Mecp2-eGFP and Nanog-PuroGFP refer to cell lines reported previously (Thomson et al., 2010), but reanalyzed for this study. (E) Diagrams depicting the influence of CGI sequence composition on chromatin structure. Upper panel: Sequences with high CpG frequency and high C + G content attract both $\mathrm{H} 3 \mathrm{~K} 4$ and H3K27 methyltransferase to establish bivalent chromatin domains and they remain unmethylated. SET1A/1B and MLL1/2 complexes contain CXXC domains that may target H3K4me3 to CGls. The mechanism by which the PRC2 complex is targeted is unknown. Middle panel: Without CpGs, H3K4 and K27 methyltransferases are not recruited even when the DNA is G + C-rich. Lower panel: A + T-rich DNA fails to form a bivalent chromatin structure, even when the $\mathrm{CpG}$ density is high and is consistently subject to de novo methylation. DOI: 10.7554/eLife.03397.010

The following figure supplements are available for figure 4:

Figure supplement 1. CpG-rich, A + T-rich DNA sequences do not form bivalent chromatin.s. DOI: 10.7554/eLife.03397.011

Figure supplement 2. DNA methylation at CpG-rich, A + T-rich DNA sequences blocks bivalent chromatin. DOI: 10.7554/eLife.03397.012

Figure supplement 3. $\mathrm{CpG}$ density and CGI length at bivalent CGls correlate positively with $\mathrm{H} 3 \mathrm{~K} 4 \mathrm{me} 3$ and H3K27me3 levels in mouse ESCs.

DOI: 10.7554 /eLife.03397.013

consistently above the thresholds (as is the case for our artificial constructs) rather than short CpG dense regions flanked by AT rich DNA, we subtracted windows with $\geq 50 \%$ GC content or $<5$ CpGs and searched for blocks of adjoining windows. Uniformly A + T-rich and CpG-rich DNA sequences of this kind were absent in the mouse genome. Even when the criteria were relaxed to include sequences of only 500 base pairs in length (the approximate minimum size of CGls), we found no examples. As A + T-rich regions are consistently DNA methylated, it seems likely that, in the absence of strong selection, the high mutation rate of 5-methylcytosine effectively resists CpG accumulation at these domains over evolutionary time.

\section{Discussion}

Epigenetic marks are often considered to be sensitive to both developmental and environmental signals. Our data reinforce the complementary view that the underlying genetic information, independent of nurture or developmental history, plays an important role in setting up CGI chromatin structures. In ESCs at least, each of the major CGI chromatin configurations is informed by DNA sequence. We find that the non-methylated state of CGls depends on G + C-rich base composition and that both the signature histone marks $\mathrm{H} 3 \mathrm{~K} 4 \mathrm{me} 3$ and $\mathrm{H} 3 \mathrm{~K} 27$ me3 depend on a high density of the non-methylated $\mathrm{CpG}$ dyad. The importance of primary DNA sequence in determining bulk features of the epigenome have been suggested elsewhere. For example, DNA sequence motifs that are recognised by transcription factors strongly influence DNA methylation patterns (Lienert et al., 2011; Stadler et al., 2011) and inter-individual variation in other epigenomic features maps to sites of human DNA sequence heterogeneity that are probably causal (Kasowski et al., 2013; Kilpinen et al., 2013; McVicker et al., 2013). Our data show that even gross features of genomic DNA, such as base composition and the frequency of the 2-base pair sequence $C p G$, influence the epigenome.

Do our findings reflect the relationship between naturally occurring DNA sequences and chromatin modification? Almost all native CGIs in mouse ESCs are non-methylated at the DNA level and coincide with peaks of $\mathrm{H} 3 \mathrm{~K} 4 \mathrm{me} 3$, which is often seen as the signature histone mark of CGls (Bernstein et al., 2006; Thomson et al., 2010). About one third of the H3K4me3-marked CGls in mouse ES cells also carry H3K27me3 and are therefore defined as bivalent (Ku et al., 2008). H3K27me3 is usually relatively dispersed compared with the discrete localisation of components of the PRC2 complex, which deposit this mark. It is estimated that at least $97 \%$ of peaks corresponding to the PRC2 component Ezh2 
coincide with CGIs ( $\mathrm{Ku}$ et al., 2008). This has led to the suggestion that polycomb is targeted to G + C-rich or CpG-rich DNA (Tanay et al., 2007; Mendenhall et al., 2010; Lynch et al., 2012; Long et al., 2013). It was shown previously that CpG density within the non-methylated CGI fraction as a whole is proportional to the H3K4me3 ChIP-seq signal in both mouse and human cells (IIlingworth et al., 2010). We asked whether the same relationship holds true for bivalent CGls and whether it also applies to H3K27me3. Within a set of 2547 exclusively bivalent promoters from mouse ESCs (Marks et al., 2012; Denissov et al., 2014), we found that 92\% coincide with CGls. Within this bivalent group, CGI length and CpG density both correlate positively with H3K4me3 and also H3K27me3 levels (Figure 4-figure supplement 3). In contrast to typical CGl-like sequences, endogenous G + C-rich, CpG-poor sequences do not display a bivalent chromatin structure. A + T-rich, CpG-rich domains of CGl-like dimensions, however, are effectively absent from the mouse genome. The sum of available data argues strongly that a high abundance of the dinucleotide CpG is a key precondition for the formation of bivalent chromatin.

A possible mechanism for recruitment of $\mathrm{H} 3 \mathrm{~K} 4 \mathrm{me} 3$ involves DNA binding by $\mathrm{H} 3 \mathrm{~K} 4$ methyltransferases, each of which is associated with a CpG-binding CXXC domain. In MII1 and MII2 the DNA binding domains are within the SET-containing protein themselves (Allen et al., 2006; Cierpicki et al., 2010), whereas in the case of Set1/COMPASS the CXXC domain resides in the Cfp1 protein component of the multi-subunit complex (Lee and Skalnik, 2005). The H3K4me3 component of bivalent CGIs in ESCs depends on MII2 (Hu et al., 2013; Denissov et al., 2014). Accordingly, we have found that bivalent CGIs form normally in Cfp1-/- ES cells. Since the binding of the CXXC domain to CpG is abolished by methylation of the cytosine moiety (Lee et al., 2001), this may explain why DNA methylation prevents the formation of H3K4me3 even in the presence of high $\mathrm{CpG}$ densities. The mechanism responsible for recruiting PRC2, which is the complex responsible for the establishment of H3K27me3, remains uncertain, as no CpG binding component of PRC2 has yet been detected. (Thomson et al., 2010; Hu et al., 2013; Wu et al., 2013). A recent study, however, indicates that the CXXC-domain protein KDM2B can target the PRC1 complex to CGls and recruit PRC2 secondarily, which would accord with our findings (Blackledge et al., 2014).

Bivalent chromatin has attracted attention due to the proposal that it represents a poised transcriptional state in pluripotent cells (Bernstein et al., 2006; Voigt et al., 2013). It is suggested that the poised state is resolved during differentiation as the affected gene becomes either transcriptionally activated or repressed. Recent evidence has clearly established that H3K27me and H3K4me can be present on the same nucleosome, albeit on different histone tails (Voigt et al., 2012). The biological significance of bivalent chromatin has recently become less certain, however. Whereas silent CGI promoters in ESCs grown in serum usually exhibit a bivalent chromatin structure, this chromatin configuration is significantly reduced in $2 \mathrm{i}$ medium, which discourages differentiation and is thought to induce a more pronounced pluripotent state (Marks et al., 2012). Also, cells in which the histone methyltransferase MII2 is depleted lose H3K4me3 at hitherto bivalent CGls, but this has no detectable effect on the induction kinetics of the associated genes upon differentiation (Hu et al., 2013). The evidence remains inconclusive, but it raises the possibility that bivalency is not an essential precondition for gene activation during differentiation. Here we find that bivalency is not confined to poised developmental genes but is a default response to any CpG-rich DNA sequences, even when these are completely artificial. It is apparent from this that the bivalent chromatin structure is not reserved for developmentally important genes, but is a response to general features of local DNA sequence.

Bulk mammalian DNA has a base composition of $40 \% \mathrm{G}+\mathrm{C}$ and is globally methylated at CpGs to an average level of $\sim 65 \%$, whereas $G+C$-rich CGls are usually DNA methylation-free. The transfection experiments reported here recapitulate this distinction as G + C-rich CGI-like DNA reproducibly resisted DNA methylation, whereas A + T-rich DNA reliably became densely methylated. Our findings raise the possibility that this broadly binary pattern of global DNA methylation may be determined by base composition. CpG density did not affect this susceptibility to methylation, which occurred even when CpG occurred at densities typical of endogenous CGls. Two simple alternative explanations are possible: either A + T-rich DNA attracts de novo methylation, or G + C-richness excludes it, leaving the bulk genome to be methylated by default. Both Dnmt 3L and Dnmt 3A have the potential to be repelled by $\mathrm{H} 3 \mathrm{~K} 4 \mathrm{me} 3$ (Jia et al., 2007; Ooi et al., 2007), suggesting that recruitment of H3K4 methyltransferases with CpG-binding CXXC domains protects CGls against de novo methylation. We find, however, that A + T-rich CpG-rich sequences are reproducibly DNA methylated despite their ability to attract $\mathrm{H} 3 \mathrm{~K} 4 \mathrm{me} 3$ when DNA methylation is absent. Since these sequences were initially 
non-methylated when transfected into cells, it may be that $\mathrm{H} 3 \mathrm{~K} 4 \mathrm{me} 3$ alone is not sufficient to exclude $\mathrm{CpG}$ methylation from these regions. This would accord with our previous observation that a moderately G + C-rich artificial CGI when inserted into ES cells was extensively methylated despite the presence of H3K4me3 on non-methylated copies (Thomson et al., 2010). Alternatively, A + T-rich CpG-rich sequences may attract $\mathrm{H} 3 \mathrm{~K} 4$ me3 less robustly than $\mathrm{G}+\mathrm{C}$-rich $\mathrm{CGls}$, thereby allowing access to de novo DNA methyltransferases.

The CGI phenomenon is conserved throughout the vertebrate lineage, but interestingly the G + C-richness characteristic of mammalian and bird CGls is not seen in some vertebrate groups (Long et al., 2013). Fish for example have non-methylated CGl-like sequences at promoters, but these are not markedly G + C-rich compared with the bulk genome (Cross et al., 1991; Long et al., 2013). Since A + T-rich sequences are susceptible to de novo DNA methylation in mammals, it follows that some vertebrate groups may rely on a different set of mechanisms to prevent methylation at $\mathrm{G}+\mathrm{C}$-poor CGls. Identifying potential components that discriminate between mammalian CGls and the bulk genome is a priority for future work.

\section{Materials and methods}

\section{Mouse ES cell lines}

ES cells were grown in gelatinized dishes in Glasgow MEM (Gibco, UK) supplemented with 15\% fetal bovine serum (Hyclone; Fisher Scientific, UK), 1\% sodium pyruvate, 1\% non-essential amino acids, $0.1 \% \beta$-mercaptoethanol, $100 \mathrm{U} / \mathrm{ml}$ penicillin, $100 \mu \mathrm{g} / \mathrm{ml}$ streptomycin and leukemia inhibitory factor (LIF). E14TG2a ES cells were used as wild-type ES cells. Cfp1-/- cells were a gift from David Skalnik and have been described previously (Carlone et al., 2005). Dnmt 3a/3b double knock out mouse ESC (DKOs) were as described (Okano et al., 1999). TC1-mES cells (a gift from Dr Ann Dean) with the hygromycin/thymidine kinase cassette in the $\beta$-globin locus (Lienert et al., 2011) were used for recombination-mediated cassette exchange. Cfp1-GFP tagged mouse ES cells have been described (Denissov et al., 2014). This integrated BAC contains the whole Cfp1 gene with regulatory elements and GFP fused to the last codon of to create a C-terminal GFP tag.

\section{Recombineering}

Custom Perl scripts were used to create random sequences with specific frequencies of $\mathrm{CpG}, \mathrm{G}+\mathrm{C}$ content and length (https://github.com/swebb1/cpg_tools). Supplementary file 1 lists the CGI-like sequences used in this study. Artificial DNAs were synthesised (GeneArt; Life Technologies, UK) and cloned into a plasmid containing a selection cassette and homology arms for recombineering. CGl-constructs were introduced into human gene desert BACs by recombineering using the Red/ET system by Gene Bridges (Germany). Briefly, bacteria containing the gene desert BAC of interest (gene

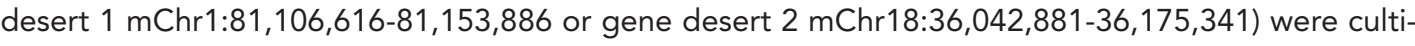
vated in LB medium plus chloramphenicol at $37^{\circ} \mathrm{C} \mathrm{o} / \mathrm{n}$. On the next day $40 \mathrm{ng}$ Red/ET plasmid were electroporated ( $1350 \mathrm{~V}, 10 \mu \mathrm{F}, 600 \mathrm{Ohms}$ ) into the cells containing the BAC and incubated in LB containing chloramphenicol and tetracycline at $30^{\circ} \mathrm{C}$ for at least $15 \mathrm{hr}$. Next day $50 \mu \mathrm{l}$ of $10 \% \mathrm{~L}$-arabinose were added to induce the expression of the Red/ET recombination proteins and samples were incubated at $37^{\circ} \mathrm{C}$ for $1 \mathrm{~h}$. Cells were electroporated with 200-300 ng of linearized DNA containing the CGI-like sequence, a kanamycin selection cassette and homology arms. Cells were re-suspended in $1 \mathrm{ml}$ of SOC medium and recovered for $1-2 \mathrm{~h}$ at $37^{\circ} \mathrm{C}$. Cells were plated on plates containing chloramphenicol and kanamycin. Plates were incubated at $37^{\circ} \mathrm{Co} / \mathrm{n}$. Colonies were screened by colony PCR and control digests for successful recombination. The linearized BAC containing the CGI-like constructs and a selection cassette was used for transfection of mESCs.

\section{ES cell transfection}

Linearized BAC DNA $(0.5-2 \mu \mathrm{g})$ containing the CGl-like sequences and a selection cassette flanked by Frt sites was used to transfect $60 \%$ confluent mouse ESC growing in a 6-well plate using Lipofectamine LTX Plus (Invitrogen, UK). DNA was made up with OptiMem (Gibco, UK) to $500 \mu \mathrm{l}, 2.5 \mu \mathrm{l}$ PLUS reagent were added and incubated for $5 \mathrm{~min}$ at RT. Afterwards $6.25 \mu$ Lipofectamine were added, incubated for $30 \mathrm{~min}$ at RT and added to the ES cells. Cells were split in a range of different ratios (10-0.1\% of transfected cells) $24 \mathrm{hr}$ after transfection and plated onto $10 \mathrm{~cm}^{2}$ dishes. Next day, selection medium containing the appropriate antibiotic (G418 $250 \mu \mathrm{g} / \mathrm{ml}$ or Blasticidin $3 \mu \mathrm{g} / \mathrm{ml}$ ) was added and cells 
were grown until colonies were ready to be picked. Clones were analysed for incorporation of the constructs by PCR and 2-3 independent clones with low copy number integration were selected for the excision of the selection cassette. Circular plasmid $(50 \mu \mathrm{g})$ containing a eukaryotic expression cassette for Flp or Dre were added to $2 \times 10^{7}$ cells and electroporated at $250 \mathrm{~V}$ and $500 \mu \mathrm{F}$ using a BioRad electroporator (GenePulser Xcell; Biorad, UK). Cells were left to recover for $20 \mathrm{~min}$ at RT and seeded at different dilutions. Next day $0.8 \mu \mathrm{g} / \mathrm{ml}$ puromycin were added for $48 \mathrm{hr}$ and cells were cultured until colonies were big enough for picking. Successful excision was confirmed by Southern blotting. Artificial CGls for insertion into the beta-Globin locus via recombination mediated cassette exchange were synthesised (GeneArt) with flanking inverted loxp sites and cloned into pBSIISK+ and electroporated into TC-1 ES cells carrying a Hygromycin/Thymidine Kinase double selection cassette in the betaGlobin locus (Lienert et al., 2011). Cells $\left(4 \times 10^{6}\right)$ were pre-selected with hygromycin for 10 days, electroporated with $25 \mu \mathrm{g}$ L1-artificial CGI-1L construct and $20 \mu \mathrm{g}$ pCAGGS-Cre and selection for positive clones with $3 \mu \mathrm{m}$ Ganciclovir was started 2 days after electroporation and continued for 8-10 days. Clones were tested for successful insertion of artificial CGIs by PCR screen and Southern Blot. For differentiation of mESC into neural precursors cells were plated ( $4 \times 106$ cells/dish) in $15 \mathrm{ml}$ EB medium (ES cell medium with 10\% FBS and no LIF). After 4 days in EB medium trans-retinoic acid (Sigma, UK) was added to start neuronal differentiation. Medium was changed every 2 days. On day 8 EBs were disrupted, trypsinized and used for formaldehyde crosslinking.

\section{Chromatin immunoprecipitation}

Chemical crosslink of chromatin was performed for $10 \mathrm{~min}$ at room temperature by addition of formaldehyde to a final concentration of $1 \%$. Crosslinking was stopped by addition of glycine to a final concentration of $0.125 \mathrm{mM}$. After $5 \mathrm{~min}$ incubation cells were washed twice with ice-cold $1 \times$ PBS. If acetylation was examined, sodium butyrate was added to the PBS. Cells were centrifuged for 5 min at $330 \times \mathrm{g}$ at $4^{\circ} \mathrm{C}$ and washed once in wash buffer $\mathrm{A}(0.25 \%$ Triton X-100, $10 \mathrm{mM}$ EDTA pH 8.0, $0.5 \mathrm{mM}$ EGTA pH 7.5, $10 \mathrm{mM}$, HEPES pH 7.5) and $\mathrm{B}(0.2 \mathrm{M} \mathrm{NaCl}, 1 \mathrm{mM}$ EDTA pH 8.0, $0.5 \mathrm{mM}$ EGTA pH 7.5, $10 \mathrm{mM}$ HEPES $\mathrm{pH}$ 7.5). Each buffer contained PMSF to a final concentration of $1 \mu \mathrm{g} / \mathrm{ml}, 1 \times$ Proteinase Inhibitor Complete Mix (Roche, UK) and $10 \mathrm{mM}$ sodium butyrate. Cells were re-suspended in lysis

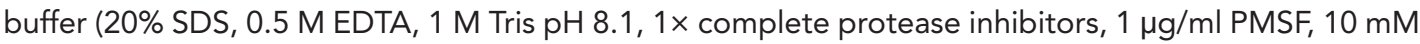
sodium butyrate). Chromatin was sheared to 400-600 base pair fragments by sonication of the cell lysate using a twin Bioruptor (Diagenode, Belgium) for 15 cycles, $30 \mathrm{~s}$ on, $30 \mathrm{~s}$ off on high setting. The lysate was centrifuged for $10 \mathrm{~min}$ at $16,000 \times \mathrm{g}$ at $4^{\circ} \mathrm{C}$ to collect cellular debris. Chromatin concentration was measured on a Nanodrop spectrophotometer. Chromatin (30 $\mu \mathrm{g}$ or $100 \mu \mathrm{g}$ ) was used for ChIP with antibodies against histone modifications or other proteins. For the ChIP, chromatin was made up to $100 \mu \mathrm{l}$ with lysis buffer and $900 \mu \mathrm{l}$ of dilution buffer $(20 \mathrm{mM}$ Tris- $\mathrm{HCl}, \mathrm{pH} 8,150 \mathrm{mM}$ $\mathrm{NaCl}, 1 \%$ Triton X-100, 1 mM EDTA) were added. Antibodies were added as specified and samples were incubated $\mathrm{o} / \mathrm{n}$ at $4{ }^{\circ} \mathrm{C}$ on a rotating wheel. The next day debris was removed by centrifugation for $5 \mathrm{~min}$ at $16,000 \times \mathrm{g}$ and $50 \mu \mathrm{l}$ dynabeads protein $\mathrm{G}$ (Life Technologies, UK) were added to the supernatant of the IPs and samples were incubated on a rotating wheel for $2 \mathrm{hr}$ at $4^{\circ} \mathrm{C}$. IPs were washed $3 \times$ with $1 \mathrm{ml}$ ice-cold wash buffer $1(20 \mathrm{mM}$ Tris- $\mathrm{HCl}, \mathrm{pH} 8,150 \mathrm{mM} \mathrm{NaCl}, 1 \%$ Triton X-100, $1 \mathrm{mM}$ EDTA, $0.1 \% \mathrm{SDS}), 2 \times$ with ice-cold wash buffer $2(20 \mathrm{mM}$ Tris- $\mathrm{HCl}, \mathrm{pH} 8,500 \mathrm{mM} \mathrm{NaCl}, 1 \%$ Triton X-100, $1 \mathrm{mM}$ EDTA, $0.1 \%$ SDS) and $1 \times$ with ice-cold TE. $100 \mu \mathrm{l}$ or $50 \mu \mathrm{l}$ of freshly prepared $10 \%$ Chelex 100 Resin (100-200 mesh, BioRad) were added to samples or input respectively. Samples were boiled for $12 \mathrm{~min}$, cooled to RT. Proteinase K ( $2 \mu \mathrm{l}$ of $20 \mathrm{mg} / \mathrm{ml}$ ) was added and incubated at $55^{\circ} \mathrm{C}$ for $30 \mathrm{~min}$ while shaking. After heating to $100^{\circ} \mathrm{C}$, samples were spun down and $60 \mu \mathrm{l}$ supernatant were transferred to fresh tubes. Each sample was made up to $300 \mu$ total volume with $10 \mathrm{mM}$ Tris $\mathrm{pH} 8,0.1 \mathrm{mM}$ EDTA and assayed by q-PCR.

\section{qPCR}

Supplementary file 1 lists the qPCR primers used in this study. qPCR was used to assess enrichment of specific regions in ChIP samples and to determine the copy number of BAC DNA inserted into the mouse genome. qPCR reactions $(10 \mu \mathrm{l}$ ) contained SYBR Green SensiMix (Bioline, UK), $250 \mathrm{nM}$ primers and $3 \mu$ l ChIP DNA or 100 ng DNA for the determination of copy numbers. PCR was carried out using a Roche Lightcycler and cycling conditions were as follows; initial denaturation at $94^{\circ} \mathrm{C}$ for 10 min followed by 45 cycles of denaturation at $94^{\circ} \mathrm{C}$ for $10 \mathrm{~s}$, primer annealing for $10 \mathrm{~s}$ and primer extension at $72^{\circ} \mathrm{C}$ for $15 \mathrm{~s}$. Using the Roche Lightcycler software, SYBR Green fluorescence measurements were plotted 
relative to cycle number and the 2 nd derivative maximum method was used to determine the cycle threshold values $(\mathrm{Ct})$ for each sample. Values for duplicate of triplicate ChIP samples were calculated as \%-input and copy number of artificial CGls was assessed relative to Sox2 qPCR signal.

\section{Antibodies}

$\alpha-H 3 K 4 m e 3$ (Abcam[UK]-8580), a-H3K4me1(Abcam-8895), a-H3K27me3 (Millipore[UK]-07-449), $\alpha-H 3 K 9 / K 14 a c$ (Abcam 12,179), a-H3 (Abcam 1791), a-SUZ12 (Abcam 12,073-100), a-RNA Pol II N20 (Santa-Cruz[UK] 899), a-RNA Pol II S5P (Abcam 5131), a-RNA Pol II unphosphorylated CTD (Abcam 817), a-GFP (Chromotec [Germany] GFP-TRAP-A gta-20), a-lgG (Invitrogen 10500C).

\section{Bisulfite genomic sequencing}

Bisulfite conversion of genomic DNA was carried out using the EpiTect Bisulfite Kit from Qiagen (UK). The converted DNA was used for PCR amplification of regions of interest, Supplementary file 2 lists the CGI-like sequences used in this study. PCR products were gel-purified and cloned using the Stratagene blunt end cloning kit. Positive clones were sent for sequencing.

\section{Acknowledgements}

We thank Ann Dean, Dirk Schubeler and David Skalnik for sharing cell lines, Sukhdeep Singh for bioinformatic insights and Martha Koerner, Matt Lyst and Sabine Lagger for critical comments on the manuscript. The work was supported by Grants from the Wellcome Trust (WT091580, WT84637, WT092076). E.W. was funded by a Wellcome Trust 4 year PhD studentship (WT086659). T.Q. holds a Marie Curie fellowship.

\section{Additional information}

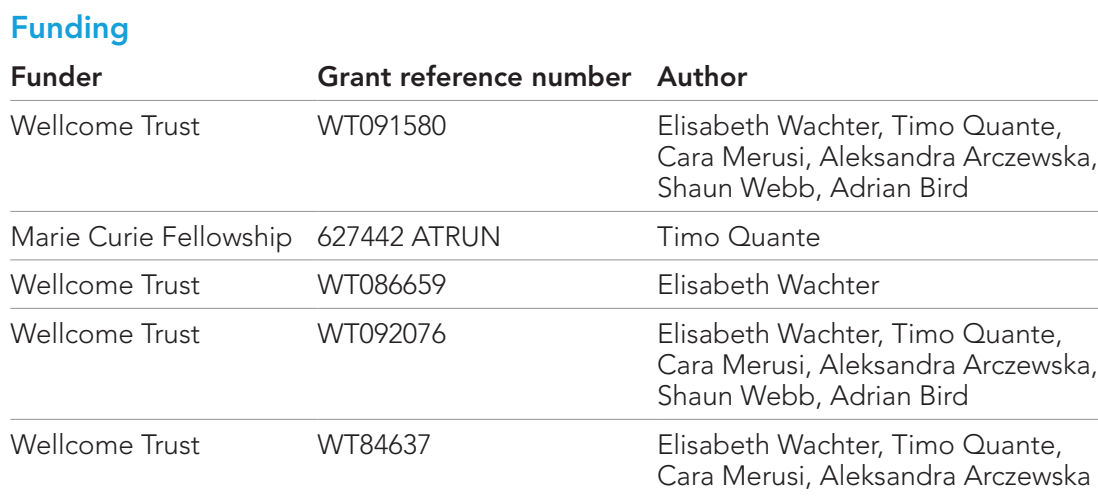

The funders had no role in study design, data collection and interpretation, or the decision to submit the work for publication.

Author contributions

EW, TQ, Conception and design, Acquisition of data, Analysis and interpretation of data, Drafting or revising the article; $\mathrm{CM}, \mathrm{AA}$, Acquisition of data, Analysis and interpretation of data, Drafting or revising the article; FS, Analysis and interpretation of data, Drafting or revising the article, Contributed unpublished essential data or reagents; SW, AB, Conception and design, Analysis and interpretation of data, Drafting or revising the article

\section{Additional files}

Supplementary files

- Supplementary file 1. CGI-like DNA sequences.

DOI: 10.7554/eLife.03397.014

- Supplementary file 2. Primers.

DOI: 10.7554/eLife.03397.015 


\section{References}

Allen MD, Grummitt CG, Hilcenko C, Min SY, Tonkin LM, Johnson CM, Freund SM, Bycroft M, Warren AJ. 2006. Solution structure of the nonmethyl-CpG-binding CXXC domain of the leukaemia-associated MLL histone methyltransferase. The EMBO Journal 25:4503-4512. doi: 10.1038/sj.emboj.7601340.

Azuara V, Perry P, Sauer S, Spivakov M, Jorgensen HF, John RM, Gouti M, Casanova M, Warnes G, Merkenschlager M, Fisher AG. 2006. Chromatin signatures of pluripotent cell lines. Nature Cell Biology 8:532-538. doi: 10.1038/ncb1403.

Bernstein BE, Mikkelsen TS, Xie X, Kamal M, Huebert DJ, Cuff J, Fry B, Meissner A, Wernig M, Plath K, Jaenisch R, Wagschal A, Feil R, Schreiber SL, Lander ES. 2006. A bivalent chromatin structure marks key developmental genes in embryonic stem cells. Cell 125:315-326. doi: 10.1016/j.cell.2006.02.041.

Bird AP. 1986. CpG-rich islands and the function of DNA methylation. Nature 321:209-213. doi: 10.1038/321209a0. Blackledge NP, Farcas AM, Kondo T, King HW, McGouran JF, Hanssen LL, Ito S, Cooper S, Kondo K, Koseki Y, Ishikura T, Long HK, Sheahan TW, Brockdorff N, Kessler BM, Koseki H, Klose RJ. 2014. Variant PRC1 complexdependent H2A ubiquitylation drives PRC2 recruitment and polycomb domain formation. Cell 157:1445-1459. doi: 10.1016/j.cell.2014.05.004.

Blackledge NP, Klose R. 2011. CpG island chromatin: a platform for gene regulation. Epigenetics 6:147-152. doi: 10.4161/epi.6.2.13640.

Blackledge NP, Zhou JC, Tolstorukov MY, Farcas AM, Park PJ, Klose RJ. 2010. CpG islands recruit a histone H3 lysine 36 demethylase. Molecular Cell 38:179-190. doi: 10.1016/j.molcel.2010.04.009.

Carlone DL, Skalnik DG. 2001. CpG binding protein is crucial for early embryonic development. Molecular and Cell Biology 21:7601-7606. doi: 10.1128/MCB.21.22.7601-7606.2001.

Carlone DL, Lee JH, Young SR, Dobrota E, Butler JS, Ruiz J, Skalnik DG. 2005. Reduced genomic cytosine methylation and defective cellular differentiation in embryonic stem cells lacking CpG binding protein. Molecular and Cellular Biology 25:4881-4891. doi: 10.1128/MCB.25.12.4881-4891.2005.

Cierpicki T, Risner LE, Grembecka J, Lukasik SM, Popovic R, Omonkowska M, Shultis DD, Zeleznik-Le NJ, Bushweller JH. 2010. Structure of the MLL CXXC domain-DNA complex and its functional role in MLL-AF9 leukemia. Nature Structural \& Molecular Biology 17:62-68. doi: 10.1038/nsmb.1714.

Clouaire T, Webb S, Skene P, Illingworth R, Kerr A, Andrews R, Lee JH, Skalnik D, Bird A. 2012. Cfp1 integrates both CpG content and gene activity for accurate H3K4me3 deposition in embryonic stem cells. Genes \& Development 26:1714-1728. doi: 10.1101/gad.194209.112.

Cross S, Kovarik P, Schmidtke J, Bird AP. 1991. Non-methylated islands in fish genomes are GC-poor. Nucleic Acids Research 19:1469-1474. doi: 10.1093/nar/19.7.1469.

Deaton AM, Bird A. 2011. CpG islands and the regulation of transcription. Genes \& Development 25:1010-1022. doi: 10.1101/gad.2037511.

Denissov S, Hofemeister H, Marks H, Kranz A, Ciotta G, Singh S, Anastassiadis K, Stunnenberg HG, Stewart AF. 2014. MII2 is required for H3K4 trimethylation on bivalent promoters in embryonic stem cells, whereas Mll1 is redundant. Development 141:526-537. doi: 10.1242/dev.102681.

Farcas AM, Blackledge NP, Sudbery I, Long HK, McGouran JF, Rose NR, Lee S, Sims D, Cerase A, Sheahan TW, Koseki H, Brockdorff N, Ponting CP, Kessler BM, Klose RJ. 2012. KDM2B links the Polycomb Repressive Complex 1 (PRC1) to recognition of CpG islands. eLife 1:e00205. doi: 10.7554/eLife.00205.

Ficz G, Hore TA, Santos F, Lee HJ, Dean W, Arand J, Krueger F, Oxley D, Paul YL, Walter J, Cook SJ, Andrews S, Branco MR, Reik W. 2013. FGF signaling inhibition in ESCs drives rapid genome-wide demethylation to the epigenetic ground state of pluripotency. Cell Stem Cell 13:351-359. doi: 10.1016/j.stem.2013.06.004.

Guenther MG, Levine SS, Boyer LA, Jaenisch R, Young RA. 2007. A chromatin landmark and transcription initiation at most promoters in human cells. Cell 130:77-88. doi: 10.1016/j.cell.2007.05.042.

Habibi E, Brinkman AB, Arand J, Kroeze LI, Kerstens HH, Matarese F, Lepikhov K, Gut M, Brun-Heath I, Hubner NC, Benedetti R, Altucci L, Jansen JH, Walter J, Gut IG, Marks H, Stunnenberg HG. 2013. Whole-genome bisulfite sequencing of two distinct interconvertible DNA methylomes of mouse embryonic stem cells. Cell Stem Cell 13:360-369. doi: 10.1016/j.stem.2013.06.002.

Hu D, Garruss AS, Gao X, Morgan MA, Cook M, Smith ER, Shilatifard A. 2013. The MIl2 branch of the COMPASS family regulates bivalent promoters in mouse embryonic stem cells. Nature Structural \& Molecular Biology 20:1093-1097. doi: 10.1038/nsmb.2653.

Illingworth RS, Gruenewald-Schneider U, Webb S, Kerr AR, James KD, Turner DJ, Smith C, Harrison DJ, Andrews R, Bird AP. 2010. Orphan CpG islands identify numerous conserved promoters in the mammalian genome. PLOS Genetics 6:e1001134. doi: 10.1371/journal.pgen.1001134.

Jia D, Jurkowska RZ, Zhang X, Jeltsch A, Cheng X. 2007. Structure of Dnmt3a bound to Dnmt3L suggests a model for de novo DNA methylation. Nature 449:248-251. doi: 10.1038/nature06146.

Kasowski M, Kyriazopoulou-Panagiotopoulou S, Grubert F, Zaugg JB, Kundaje A, Liu Y, Boyle AP, Zhang QC, Zakharia F, Spacek DV, Li J, Xie D, Olarerin-George A, Steinmetz LM, Hogenesch JB, Kellis M, Batzoglou S, Snyder M. 2013. Extensive variation in chromatin states across humans. Science 342:750-752. doi: 10.1126/ science.1242510.

Kilpinen H, Waszak SM, Gschwind AR, Raghav SK, Witwicki RM, Orioli A, Migliavacca E, Wiederkehr M, Gutierrez-Arcelus M, Panousis NI, Yurovsky A, Lappalainen T, Romano-Palumbo L, Planchon A, Bielser D, Bryois J, Padioleau I, Udin G, Thurnheer S, Hacker D, Core LJ, Lis JT, Hernandez N, Reymond A, Deplancke B, Dermitzakis ET. 2013. Coordinated effects of sequence variation on DNA binding, chromatin structure, and transcription. Science 342:744-747. doi: 10.1126/science.1242463. 
Ku M, Koche RP, Rheinbay E, Mendenhall EM, Endoh M, Mikkelsen TS, Presser A, Nusbaum C, Xie X, Chi AS, Adli M, Kasif S, Ptaszek LM, Cowan CA, Lander ES, Koseki H, Bernstein BE. 2008. Genomewide analysis of PRC1 and PRC2 occupancy identifies two classes of bivalent domains. PLOS Genetics 4:e1000242. doi: 10.1371/journal.pgen.1000242.

Lee JH, Skalnik DG. 2005. CpG-binding protein (CXXC finger protein 1) is a component of the mammalian Set1 histone H3-Lys4 methyltransferase complex, the analogue of the yeast Set1/COMPASS complex. The Journal of Biological Chemistry 280:41725-41731. doi: 10.1074/jbc.M508312200.

Lee JH, Voo KS, Skalnik DG. 2001. Identification and characterization of the DNA binding domain of CpGbinding protein. The Journal of Biological Chemistry 276:44669-44676. doi: 10.1074/jbc.M107179200.

Lienert F, Wirbelauer C, Som I, Dean A, Mohn F, Schubeler D. 2011. Identification of genetic elements that autonomously determine DNA methylation states. Nature Genetics 43:1091-1097. doi: 10.1038/ng.946.

Long HK, Sims D, Heger A, Blackledge NP, Kutter C, Wright ML, Grutzner F, Odom DT, Patient R, Ponting CP, Klose RJ. 2013. Epigenetic conservation at gene regulatory elements revealed by non-methylated DNA profiling in seven vertebrates. eLife 2:e00348. doi: 10.7554/eLife.00348.

Lynch MD, Smith AJ, De Gobbi M, Flenley M, Hughes JR, Vernimmen D, Ayyub H, Sharpe JA, Sloane-Stanley JA, Sutherland L, Meek S, Burdon T, Gibbons RJ, Garrick D, Higgs DR. 2012. An interspecies analysis reveals a key role for unmethylated $\mathrm{CpG}$ dinucleotides in vertebrate Polycomb complex recruitment. The EMBO Journal 31:317-329. doi: 10.1038/emboj.2011.399.

Marks H, Kalkan T, Menafra R, Denissov S, Jones K, Hofemeister H, Nichols J, Kranz A, Stewart AF, Smith A, Stunnenberg HG. 2012. The transcriptional and epigenomic foundations of ground state pluripotency. Cell 149:590-604. doi: 10.1016/j.cell.2012.03.026.

McVicker G, van de Geijn B, Degner JF, Cain CE, Banovich NE, Raj A, Lewellen N, Myrthil M, Gilad Y, Pritchard JK. 2013. Identification of genetic variants that affect histone modifications in human cells. Science 342:747-749. doi: 10.1126/science.1242429.

Mendenhall EM, Koche RP, Truong T, Zhou VW, Issac B, Chi AS, Ku M, Bernstein BE. 2010. GC-rich sequence elements recruit PRC2 in mammalian ES cells. PLOS Genetics 6:e1001244. doi: 10.1371/journal.pgen.1001244.

Okano M, Bell DW, Haber DA, Li E. 1999. DNA methyltransferases Dnmt3a and Dnmt3b are essential for de novo methylation and mammalian development. Cell 99:247-257. doi: 10.1016/S0092-8674(00)81656-6.

Ooi SK, Qiu C, Bernstein E, Li K, Jia D, Yang Z, Erdjument-Bromage H, Tempst P, Lin SP, Allis CD, Cheng X, Bestor TH. 2007. DNMT3L connects unmethylated lysine 4 of histone $\mathrm{H} 3$ to de novo methylation of DNA. Nature 448:714-717. doi: 10.1038/nature05987.

Stadler MB, Murr R, Burger L, Ivanek R, Lienert F, Scholer A, van Nimwegen E, Wirbelauer C, Oakeley EJ, Gaidatzis D, Tiwari VK, Schübeler D. 2011. DNA-binding factors shape the mouse methylome at distal regulatory regions. Nature 480:490-495. doi: 10.1038/nature10716.

Tanay A, O'Donnell AH, Damelin M, Bestor TH. 2007. Hyperconserved CpG domains underlie Polycomb-binding sites. Proceedings of the National Academy of Sciences of USA 104:5521-5526. doi: 10.1073/pnas.0609746104.

Thomson JP, Skene PJ, Selfridge J, Clouaire T, Guy J, Webb S, Kerr AR, Deaton A, Andrews R, James KD, Turner DJ, Illingworth R, Bird A. 2010. CpG islands influence chromatin structure via the CpG-binding protein Cfp1. Nature 464:1082-1086. doi: 10.1038/nature08924.

Voigt P, LeRoy G, Drury WJ III, Zee BM, Son J, Beck DB, Young NL, Garcia BA, Reinberg D. 2012. Asymmetrically modified nucleosomes. Cell 151:181-193. doi: 10.1016/j.cell.2012.09.002.

Voigt P, Tee WW, Reinberg D. 2013. A double take on bivalent promoters. Genes \& Development 27:1318-1338. doi: 10.1101/gad.219626.113.

Wu X, Johansen JV, Helin K. 2013. Fbxl10/Kdm2b recruits polycomb repressive complex 1 to CpG islands and regulates H2A ubiquitylation. Molecular Cell 49:1134-1146. doi: 10.1016/j.molcel.2013.01.016. 